Article

\title{
Assessment of By-Product from Botryosphaeria rhodina MAMB-05 as an Effective Biosorbent of $\mathrm{Pb}(\mathrm{II})$
}

\author{
Antonio J. Muñoz ${ }^{1, *(\mathbb{D}}$, Francisco Espínola 1,2®D, Encarnación Ruiz ${ }^{1,2}$, \\ Aneli M. Barbosa-Dekker ${ }^{3}$, Robert F. H. Dekker ${ }^{4}$ (D) and Eulogio Castro ${ }^{1,2}$ (D) \\ 1 Department of Chemical, Environmental and Materials Engineering, Universidad de Jaén, Campus Las \\ Lagunillas, 23071 Jaén, Spain; fespino@ujaen.es (F.E.); eruiz@ujaen.es (E.R.); ecastro@ujaen.es (E.C.) \\ 2 Centre for Advanced Studies in Energy and Environment (CEAEMA), Universidad de Jaén, Campus Las \\ Lagunillas, 23071 Jaén, Spain \\ 3 Departamento de Química, CCE - Universidade Estadual de Londrina, Londrina - Paraná CEP: 86051-990, \\ Brazil; anelibarbosa@gmail.com \\ 4 Programa de Pós Graduação em Engenharia Ambiental, Universidade Tecnológica Federal do Paraná, \\ Câmpus Londrina, Londrina - Paraná CEP: 86036-370, Brazil; xylanase@gmail.com \\ * Correspondence: amcobo@ujaen.es; Tel.: +34953212948
}

Received: 1 July 2019; Accepted: 8 September 2019; Published: 11 September 2019

check for updates

\begin{abstract}
In this work, two types of biomass preparations (VMSM and M3) from the filamentous fungus Botryosphaeria rhodina MAMB-05, which were previously used in a process of production of $\beta$-glucan, were assessed as biosorbents of lead. The operating conditions, optimized through response surface methodology and experimental design, were shown to be $\mathrm{pH} 5.29$ and a biosorbent dose of $0.23 \mathrm{~g} / \mathrm{L}$ for the VMSM biomass type; and $\mathrm{pH} 5.06$ and a dose of biosorbent of $0.60 \mathrm{~g} / \mathrm{L}$ for the $\mathrm{M} 3$ biomass type, at a constant temperature of $27^{\circ} \mathrm{C}$. Fourier transform-infrared spectroscopy analyzed the presence of functional groups on the biomass surface. In addition to give an extra value to the by-product biomass, the VMSM-type from B. rhodina MAMB-05 showed an excellent lead biosorption capacity $\left(\mathrm{q}_{\mathrm{m}}\right)$ with a value of $403.4 \mathrm{mg} / \mathrm{g}$ for the Langmuir model, comparing favorably with literature results, while the M3 subtype biomass showed a value of $96.05 \mathrm{mg} / \mathrm{g}$.
\end{abstract}

Keywords: residual biomass; lead; biosorption; SEM; FT-IR

\section{Introduction}

Although major legislative efforts have been made to address the issue, lead and its compounds remain one of the most environmentally problematic heavy metals. Its use in numerous industries causes many natural ecosystems to become contaminated with this toxic metal [1]. The anthropic ecosystems also suffer this problem, generating public health concerns [2]. In 2017 according to the data collected by the Spanish Register of Emissions and Pollutant Sources 25,840 kg of lead were released into the atmosphere and 3,183 $\mathrm{kg}$ were released into natural waters [3]. Lead is a metal that can have a powerful toxic effect on living organisms, and also has a bioaccumulative characteristic in that it can be passed onto the food chain [4]. In recent decades, the introduction of process technologies capable of eliminating lead from wastewater has become widespread. Physico-chemical procedures are currently in general use, for example, ion exchange, chemical precipitation, adsorption, oxidation-reduction processes, and membrane technologies among others. These treatment techniques are costly, but are very effective when the contaminant is present in high concentrations [5]. Conversely, lead presents problems when its concentration is low $(<100 \mathrm{mg} / \mathrm{L})$, as the effectiveness of its removal becomes very limited [6]. In this case, work on its removal at low concentrations has been carried out since the 1960s on developing ecologically-friendly and low-cost technologies that are also very effective. 
These technologies can include biosorption of heavy metals [7,8], and have employed several types of biomass (bacteria, fungi, yeasts, algae and plant biomass) that can be active or inactive. When the biomass used is considered a waste product arising from large-scale industrial processes, biosorption takes on an added value [6].

Botryosphaeria rhodina MAMB-05, a filamentous, ascomyceteous fungus, is known to produce a variety of bioproducts by submerged fermentation $(\mathrm{SmF})$ when cultivated on different carbon sources $[9,10]$. This fungal strain was shown to be ligninolytic and could tolerate and degrade high concentrations of aromatic and phenolic compounds, demonstrating its potential for use in the bioremediation of aromatic compounds [11]. In seeking wider applications for this fungal isolate, we were interested in determining whether the mycelial fraction (biomass) could find applications as a biosorbent to remove heavy metals from ecosystems and industrial effluents. This biomass has proven effective in the biosorption of lanthanides [12].

In this work, two types of biomass (VMSM and M3) from B. rhodina MAMB-05 grown on different nutrient media containing sucrose were evaluated for their potential in the biosorption of $\mathrm{Pb}$ (II) using metal solutions at low concentration of lead $(100 \mathrm{mg} / \mathrm{L})$. The two types of fungal biomass were analyzed by Fourier Transform-infrared spectroscopy (FT-IR) to identify potential functional groups that can bind $\mathrm{Pb}$ (II). The optimal operating conditions for the biosorption of $\mathrm{Pb}(\mathrm{II})$ were determined by Response Surface Methodology (RSM). A kinetic and equilibrium study was also carried out for the biosorption process of $\mathrm{Pb}(\mathrm{II})$, and finally, the mechanisms involved in binding lead were identified by scanning electron microscopy (SEM) coupled to an energy dispersive X-ray (EDX) detector.

\section{Results and Discussion}

\subsection{Fungal Biomass Preparation as Biosorbent}

The two fungal mycelial preparations (biomass) of B. rhodina MAMB-05 represent the total cellular components, cytoplasm, and cell wall, including residual amounts of fermentation-derived biomolecules from the fungal growth on sucrose as carbon source. The biomass was collected by centrifugation and was not washed, but simply slurried in a small amount of water followed by autoclaving to sterilize the preparation, and then freeze-dried. The difference between the two nutrient media was in the composition of the mineral salts used. VMSM-biomass was produced when the fungus was cultivated on a minimum salts medium developed by Vogel [13]. M3 biomass was obtained using a modified medium [14], which also contained yeast extract $(1 \mathrm{~g} / \mathrm{L})$. Yeast extract from baker's or brewer's yeast is commonly employed in cultivating microorganisms. It is a cell-free extract rich in proteins, amino acids, carbohydrates, vitamins, and minerals. The cell wall of B. rhodina MAMB-05 contains a mix of proteins and polysaccharides, among which are $\alpha$ - and $\beta$-D-glucans [15]. The different composition of the 2 nutrient media would thus influence the biosorbent properties of the two-biomass preparations, as we demonstrate in this work.

\subsection{FT-IR Spectroscopy Study}

FT-IR analysis is based on the excitation of the molecular groups of the biological sample by infra-red (IR) radiation, which causes vibrational movements in molecular bonds: tensions and flexures that can be symmetrical or asymmetrical. The atoms of a chemical bond have vibrational movements that are within the IR range $\left(4000-650 \mathrm{~cm}^{-1}\right)$, so that when the frequency of the emitted wave coincides with that of the bond, this radiation is absorbed, generating a characteristic peak in the spectrum that allows us to identify the functional group present in the sample [16].

Figure 1 shows the FT-IR spectra for biomass preparations M3 and VMSM obtained before and after the biosorption of lead. The spectra reveal a large number of functional groups on the surface of both fungal biosorbents. The functional groups were characterized as amino, carboxylic, carbonyl, hydroxyl, methyl, methylene, and phosphate, and are similar to those reported by others in the 
scientific literature [17-20]. The integration of the peaks with the OPUS 7.0 software also showed significant changes in signal strength after biosorption (the data indicating this is not shown).

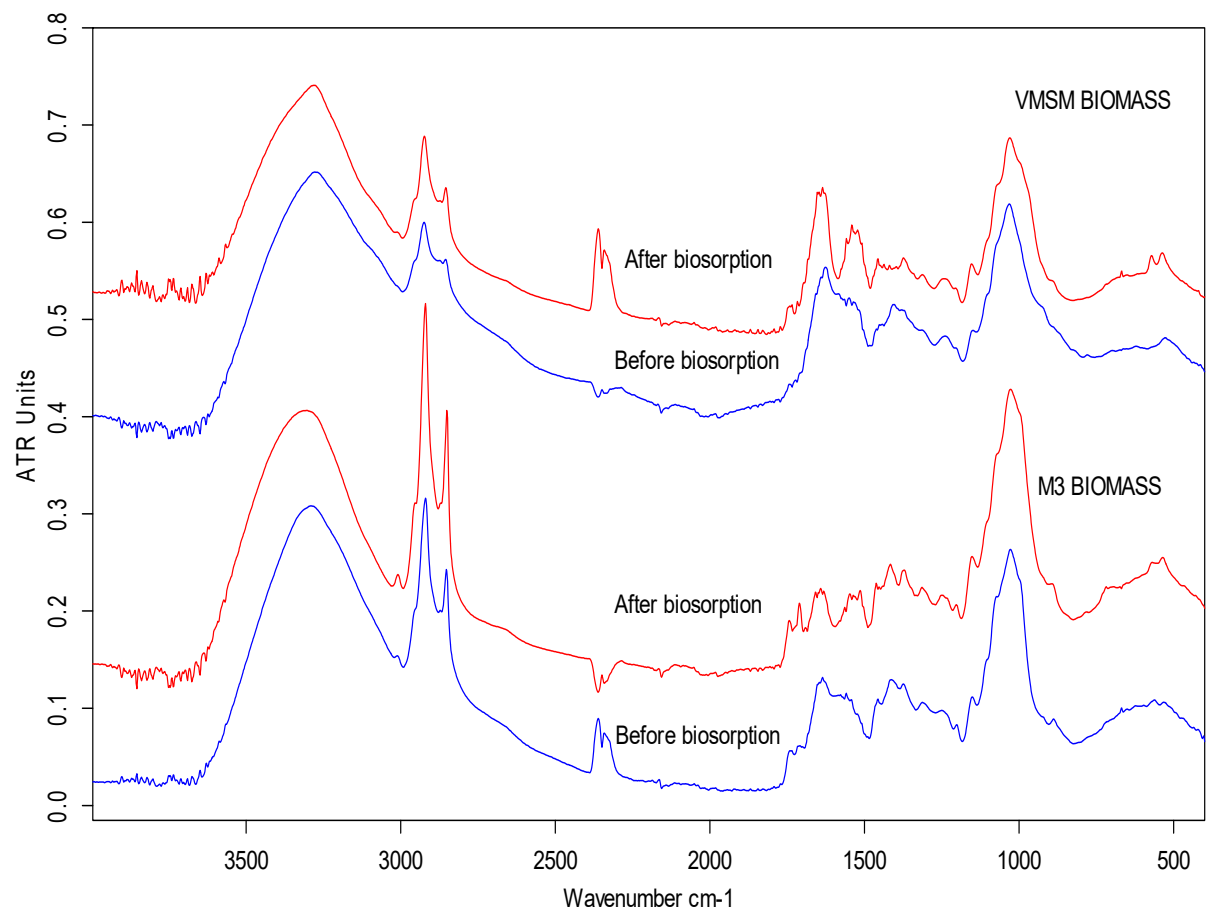

Figure 1. FT-IR spectra of M3 and VMSM biomass preparations derived from Botryosphaeria rhodina MAMB-05 before and after biosorption of $\mathrm{Pb}(\mathrm{II})$.

The assignment of the main functional groups in the FT-IR spectra for both biomass preparations reveals their involvement in the biosorption, as indicated in Table 1. The main functional groups found were: amino, methyl, carbonyl, and phosphate. Strong involvement of protein bonds C-N, $\mathrm{C}-\mathrm{O}$, and $\mathrm{N}-\mathrm{H}$ (amide I and II), as well as anionic groups such as phosphate and carboxylate were also observed, especially in the VMSM biomass, which appeared to have a greater number of peaks following the biosorption process. Similarly, in the spectral region below $900 \mathrm{~cm}^{-1}$, there was a strong shift in some peaks, and new peaks appeared. This region includes the fingerprint region and contains bands that are associated with biological macromolecules, and this presents difficulties in determining what functional groups participate in the biosorption process [21]. However, the involvement of C-H bonds and N-containing bioligands is clearly demonstrated. Deformational modes of CCO groups belonging to carbohydrates may also be involved in biosorption phenomena [22].

FT-IR spectral analyses indicated that the two types of fungal biomass presented potential for use in lead bioadsorption. The main changes occurred in the protein region (1200-1800 $\left.\mathrm{cm}^{-1}\right)$, which showed the participation of functional groups derived from proteins in the lead biosorption process [20]. However, spectral data from the VMSM biomass preparation implied a greater number of functional groups, and therefore was a priori more effective in the removal of lead from solution. This hypothesis was confirmed in the equilibrium tests. 
Table 1. The main FT-IR peaks involved in the process of biosorption of Pb(II) by the 2 types of Botryosphaeria rhodina MAMB-05 biomass, and possible assignments of the functional groups.

\begin{tabular}{|c|c|c|c|c|c|c|c|}
\hline \multicolumn{3}{|c|}{ M3 Biomass (peaks $\mathrm{cm}^{-1}$ ) } & \multicolumn{3}{|c|}{ VMSM Biomass (peaks cm ${ }^{-1}$ ) } & \multirow[b]{2}{*}{ Functional Groups } & \multirow[b]{2}{*}{ Possible Assignment } \\
\hline Before & After & Shift & Before & After & Shift & & \\
\hline \multirow[t]{2}{*}{3290} & 3303 & 13 & & & & $\mathrm{O}-\mathrm{H}, \mathrm{N}-\mathrm{H}$ & Stretching vibrations of amino and hydroxyl groups \\
\hline & & & _- & 3012 & 3012 & $-\mathrm{CH}_{3}$ & $-\mathrm{CH}_{3}$ asymmetric stretching \\
\hline 1792 & 1786 & 6 & 1797 & 1792 & 5 & $\mathrm{C}=\mathrm{O}$ & $\mathrm{C}=\mathrm{O}$ stretching \\
\hline \multirow[t]{3}{*}{1771} & 1778 & 7 & & & & $\mathrm{C}=\mathrm{O}$ & $\mathrm{C}=\mathrm{O}$ stretching \\
\hline & & & - & 1734 & 1734 & $\mathrm{C}=\mathrm{O}$ & $\mathrm{C}=\mathrm{O}$ stretching \\
\hline & & & 1723 & 1717 & 6 & $\mathrm{C}=\mathrm{O}$ & $\mathrm{C}=\mathrm{O}$ stretching \\
\hline 1700 & 1691 & 9 & & & & $-\mathrm{CO} . \mathrm{C}-\mathrm{N}, \mathrm{N}-\mathrm{H}$ & $-\mathrm{CO},-\mathrm{CN}$ stretching and $-\mathrm{NH}$ bending vibration (amide I) \\
\hline 1652 & 1658 & 6 & 1657 & 1652 & 5 & $-\mathrm{CO} . \mathrm{C}-\mathrm{N}, \mathrm{N}-\mathrm{H}$ & $-\mathrm{CO},-\mathrm{CN}$ stretching and $-\mathrm{NH}$ bending vibration (amide I) \\
\hline 1646 & 1649 & 3 & - & 1647 & 1647 & $-\mathrm{CO} . \mathrm{C}-\mathrm{N}, \mathrm{N}-\mathrm{H}$ & $-\mathrm{CO},-\mathrm{CN}$ stretching and $-\mathrm{NH}$ bending vibration (amide I) \\
\hline 1636 & 1642 & 6 & 1640 & 1636 & 4 & $-\mathrm{CO} . \mathrm{C}-\mathrm{N}, \mathrm{N}-\mathrm{H}$ & $-\mathrm{CO},-\mathrm{CN}$ stretching and $-\mathrm{NH}$ bending vibration (amide I) \\
\hline - & 1631 & 1631 & & & & $-\mathrm{CO}$ & -CO stretching amide I \\
\hline 1559 & 1564 & 5 & 1565 & 1558 & 7 & $\mathrm{~N}-\mathrm{H}, \mathrm{C}-\mathrm{N}$ & $\mathrm{C}-\mathrm{N}$ stretching in amide II group and $\mathrm{N}-\mathrm{H}$ bending vibration \\
\hline 1542 & 1547 & 5 & 1549 & 1541 & 8 & $\mathrm{~N}-\mathrm{H}, \mathrm{C}-\mathrm{N}$ & $\mathrm{C}-\mathrm{N}$ stretching in amide II group and $\mathrm{N}-\mathrm{H}$ bending vibration. \\
\hline \multirow{2}{*}{1523} & 1536 & 13 & - & 1522 & 1522 & $\mathrm{~N}-\mathrm{H}, \mathrm{C}-\mathrm{N}$ & $\mathrm{C}-\mathrm{N}$ stretching in amide II group and $\mathrm{N}-\mathrm{H}$ bending vibration. \\
\hline & & & - & 1509 & 1509 & $\mathrm{~N}-\mathrm{H}, \mathrm{C}-\mathrm{N}$ & $\mathrm{C}-\mathrm{N}$ stretching in amide II group and $\mathrm{N}-\mathrm{H}$ bending vibration. \\
\hline \multirow{2}{*}{1490} & 1514 & 28 & & & & $-\mathrm{CH}$ & $-\mathrm{CH}$ bending \\
\hline & & & 1484 & 1480 & 4 & $-\mathrm{CH}_{2},-\mathrm{CO}$ & $-\mathrm{CH}$ bending, symmetric $\mathrm{C}=\mathrm{O}$ \\
\hline - & 1462 & 1462 & 1461 & 1457 & 4 & $-\mathrm{CH}_{2},-\mathrm{OH}, \mathrm{C}=\mathrm{O}$ & -CH bend. Deformations, $\mathrm{OH}$ bend. in carboxylic groups, sym. $\mathrm{C}=\mathrm{O}$ \\
\hline 1457 & 1453 & 4 & & & & $-\mathrm{CH}_{2},-\mathrm{CO}$ & $-\mathrm{CH}$ bending, symmetric $\mathrm{C}=\mathrm{O}$ \\
\hline \multirow[t]{4}{*}{ - } & 1441 & 1441 & 1442 & 1437 & 5 & $-\mathrm{CH}_{2},-\mathrm{CO}$ & $-\mathrm{CH}$ bending, symmetric $\mathrm{C}=\mathrm{O}$ \\
\hline & & & - & 1419 & 1419 & $-\mathrm{CH}, \mathrm{C}-\mathrm{N}, \mathrm{C}=\mathrm{O}$ & C-H stretching, C-H rocking, C-N stretching \\
\hline & & & 1405 & 1397 & 14 & $\mathrm{~N}-\mathrm{H}, \mathrm{C}-\mathrm{N}, \mathrm{COO}^{-}$ & $\mathrm{N}-\mathrm{H}$ bend. in the amine group; $\mathrm{C}-\mathrm{N}$ stretch.; $\mathrm{C}=\mathrm{O}$ str (sym) of $\mathrm{COO}^{-}$ \\
\hline & & & 1397 & 1374 & 5 & $-\mathrm{CH}$ & $\mathrm{C}-\mathrm{H}$ bending vibrations \\
\hline \multirow[t]{3}{*}{-} & 1334 & 1334 & & & & $-\mathrm{CH}$ & $\mathrm{C}-\mathrm{H}$ bending vibrations \\
\hline & & & 1239 & 1243 & 4 & $-\mathrm{PO}_{2}^{-},-\mathrm{CO}$ & $\begin{array}{l}\mathrm{P}=\mathrm{O} \text { stretching of phosphodiester, or monoester phosphate groups; C-O-C, C-O-P, P-O-P } \\
\text { ring vibrations of polysaccharides }\end{array}$ \\
\hline & & & - & 1205 & 1205 & C-O-C, C-O-P, P-O-P & C-O-C, C-O-P, P-O-P ring vibrations of polysaccharides \\
\hline 888 & 893 & 5 & & & & $\mathrm{PO}_{2}{ }^{-},-\mathrm{CH}$ & C-O-C, C-O-P, P-O-P ring vibrations of polysaccharides; C-H bending (aromatic compounds) \\
\hline - & 782 & 782 & & & & & Deformational modes of the CCO groups; Nitro compounds and disulfide groups \\
\hline - & 718 & 718 & & & & $-\mathrm{CH}_{2}$ & C-H rocking \\
\hline \multirow{4}{*}{668} & 673 & 5 & 673 & 668 & 5 & & Deformational modes of the CCO groups; Nitro compounds and disulfide groups \\
\hline & & & 621 & 617 & 4 & & Deformational modes of the CCO groups; Nitro compounds and disulfide groups \\
\hline & & & 595 & 603 & 8 & & Deformational modes of the CCO groups; Nitro compounds and disulfide groups \\
\hline & & & - & 571 & 571 & $-\mathrm{CH}$ & $\mathrm{C}-\mathrm{H}$ bending vibrations (aromatics) \\
\hline 562 & 569 & 7 & & & & & Deformational modes of the CCO groups; Nitro compounds and disulfide groups \\
\hline 532 & 536 & 4 & 527 & 537 & 10 & & Deformational modes of the CCO groups; Nitro compounds and disulfide groups \\
\hline 476 & 467 & 9 & 427 & 420 & 7 & & Deformational modes of the CCO groups; Nitro compounds and disulfide groups \\
\hline
\end{tabular}




\subsection{Optimum Operating Conditions for Pb(II) Bioadsorption: Response Surface Methodology}

An experimental statistical design was carried out to study the optimal operating conditions of the factors involved in the biosorption process. Table 2 shows the experimental results obtained for biosorption capacity (q) in equilibrium conditions ranging from 55.39 to $68.45 \mathrm{mg} \mathrm{Pb}(\mathrm{II}) / \mathrm{g}$ dry biomass for M3 biomass, and 94.93 to $224.91 \mathrm{mg} \mathrm{Pb}(\mathrm{II}) / \mathrm{g}$ dry biomass for VMSM biomass.

Table 2. Rotatable Central Composite Design (RCCD) for the optimization of biosorption of Pb(II) by the 2 types of biomass (VMSM and M3) from Botryosphaeria rhodina MAMB-05.

\begin{tabular}{cccc}
\hline \multicolumn{2}{c}{ Factors } & \multicolumn{3}{c}{ Responses } \\
\hline $\mathbf{B}^{\mathbf{1}} \mathbf{( g / L )}$ & $\mathbf{p H}$ & $\mathbf{q e}^{\mathbf{2}}$ VMSM Biomass (mg/g) & $\mathbf{q e}_{\mathbf{e}}$ M3 Biomass (mg/g) \\
\hline 0.55 & 4.77 & 159.05 & 67.96 \\
0.55 & 4.77 & 159.03 & 67.53 \\
0.55 & 4.03 & $145.76^{*}$ & 56.69 \\
1.00 & 4.77 & 94.93 & 63.25 \\
0.55 & 4.77 & 158.44 & 67.96 \\
0.55 & 4.77 & 159.22 & 68.45 \\
0.55 & 5.51 & 162.95 & $72.36^{*}$ \\
0.87 & 4.25 & 107.59 & 62.05 \\
0.23 & 4.25 & 158.61 & 55.39 \\
0.10 & 4.77 & 202.10 & 58.70 \\
0.23 & 5.29 & 224.91 & 65.65 \\
0.55 & 4.77 & 165.65 & 68.15 \\
0.87 & 5.29 & 105.76 & 65.06
\end{tabular}

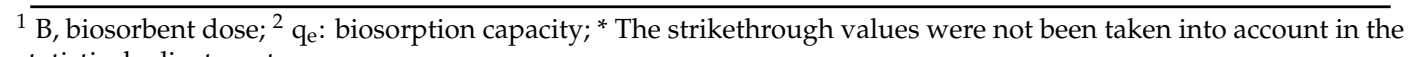
statistical adjustment.

From the subsequent statistical adjustment (Design-Expert@software, Minneapolis, MN, USA), Equation (1) for M3 and Equation (2) for VMSM were obtained.

$$
\begin{aligned}
& q_{e}=-248.235+93.0889 B+114.531 p H-10.8924 B p H-32.9522 B^{2}-10.6679 p H^{2} \\
& q_{e}=-832.580+417.015 B+353.918 p H-102.359 B p H-49.4909 B^{2}-28.1801 p H^{2}
\end{aligned}
$$

where $B$ is the biosorbent dose $(\mathrm{g} / \mathrm{L})$.

Table 3 shows the results of the analysis of variance (ANOVA) for the M3 and VMSM biomass preparations, and the variability associated with each factor and their interactions. Only statistically significant terms were included; those with $p$-values less than 0.05 (95\% confidence level).

The model F-values for both biomass preparations, 201.31 for M3, and 167.13 for VMSM, show that the models were significant, and the lack of Fit F-value, 0.0958 for M3 and 0.1067 for VMSM, show that the Lack of Fit was not significant relative to the pure error. The R-Squared statistic indicated that the models explained $99.41 \%$ of the variability for the qe values for M3 biomass, and $99.29 \%$ for VMSM biomass. In conclusion, the models appropriately predicted the biosorption capacity as a function of the two considered factors: $\mathrm{B}$ (biosorbent dose) and $\mathrm{pH}$.

The effects of the factors involved in the biosorption process were also analyzed from B. rhodina MAMB-05. The most relevant factor was the dose of biosorbent (B), while the $\mathrm{pH}$ of the solution during the biosorption process showed a limited effect within the range studied, especially in the case of the VMSM biomass (Figure 2). This was also shown in the response surface plots for both biomass preparations (Figure 3). A negative effect was observed for the biosorption capacity of $\mathrm{Pb}$ (II) with the VMSM biomass preparation as the biosorbent dose was increased.

Beginning with Equations (1) and (2), the optimal operating conditions for biosorption of $\mathrm{Pb}$ (II) were obtained for the two types of biomass: $\mathrm{pH} 5.29$ and a biosorbent dose of $0.23 \mathrm{~g} / \mathrm{L}$ for VMSM; and 
pH 5.06 and a dose of biosorbent of $0.60 \mathrm{~g} / \mathrm{L}$ for M3, at a constant temperature of $27^{\circ} \mathrm{C}$. From these values, a respective biosorption capacity of 219.81 and $69.08 \mathrm{mg} \mathrm{Pb}(\mathrm{II}) / \mathrm{g}$ dry biomass was obtained.

Table 3. Statistical parameters for the analysis of variance (ANOVA) for the quadratic model of biosorption capacity.

\begin{tabular}{|c|c|c|c|c|c|}
\hline Source of Biomass & Sum of Squares & Degree of Freedom & Mean Square & F-Value & $\begin{array}{l}p \text {-Value } \\
\text { Prob }>\text { F }\end{array}$ \\
\hline \multicolumn{6}{|l|}{ M3 } \\
\hline Model & 243.16 & 5 & 48.63 & 201.31 & $<0.0001$ \\
\hline B: Biosorbent dose & 19.55 & 1 & 19.55 & 80.91 & 0.0001 \\
\hline $\mathrm{pH}$ & 59.47 & 1 & 59.47 & 246.19 & $<0.0001$ \\
\hline $\mathrm{B} \mathrm{pH}$ & 13.14 & 1 & 13.14 & 54.40 & 0.0003 \\
\hline $\mathrm{B}^{2}$ & 73.85 & 1 & 73.85 & 305.72 & $<0.0001$ \\
\hline $\mathrm{pH}^{2}$ & 35.04 & 1 & 35.04 & 145.03 & $<0.0001$ \\
\hline Residual & 1.45 & 6 & 0.24 & & \\
\hline Lack of fit & 1.00 & 2 & 0.50 & 4.46 & 0.0958 \\
\hline Pure error & 0.45 & 4 & 0.11 & & \\
\hline Cor total & 244.61 & 11 & & & \\
\hline C.V.\% & 0.77 & & & & \\
\hline R-Squared & 0.9941 & & & & \\
\hline Adj. R-Squared & 0.9891 & & & & \\
\hline Pred. R-Squared & 0.9599 & & & & \\
\hline Adeq. Precision & 37.850 & & & & \\
\hline \multicolumn{6}{|l|}{ VMSM } \\
\hline Model & $155,26.71$ & 5 & 3105.34 & 167.13 & $<0.0001$ \\
\hline B: Biosorbent dose & $129,38.88$ & 1 & $129,38.88$ & 696.37 & $<0.0001$ \\
\hline $\mathrm{pH}$ & 1075.23 & 1 & 1075.23 & 57.87 & 0.0003 \\
\hline $\mathrm{B}$ pH & 1160.42 & 1 & 1160.42 & 62.45 & 0.0002 \\
\hline $\mathrm{B}^{2}$ & 166.59 & 1 & 166.59 & 8.97 & 0.0242 \\
\hline $\mathrm{pH}^{2}$ & 244.48 & 1 & 244.48 & 13.16 & 0.0110 \\
\hline Residual & 111.48 & 6 & 18.58 & & \\
\hline Lack of fit & 75.06 & 2 & 37.53 & 4.12 & 0.1067 \\
\hline Pure error & 36.42 & 4 & 9.11 & & \\
\hline Cor total & $156,38.19$ & 11 & & & \\
\hline C.V.\% & 2.78 & & & & \\
\hline R-Squared & 0.9929 & & & & \\
\hline Adj. R-Squared & 0.9869 & & & & \\
\hline Pred. R-Squared & 0.9211 & & & & \\
\hline Adeq. Precision & 41.515 & & & & \\
\hline
\end{tabular}
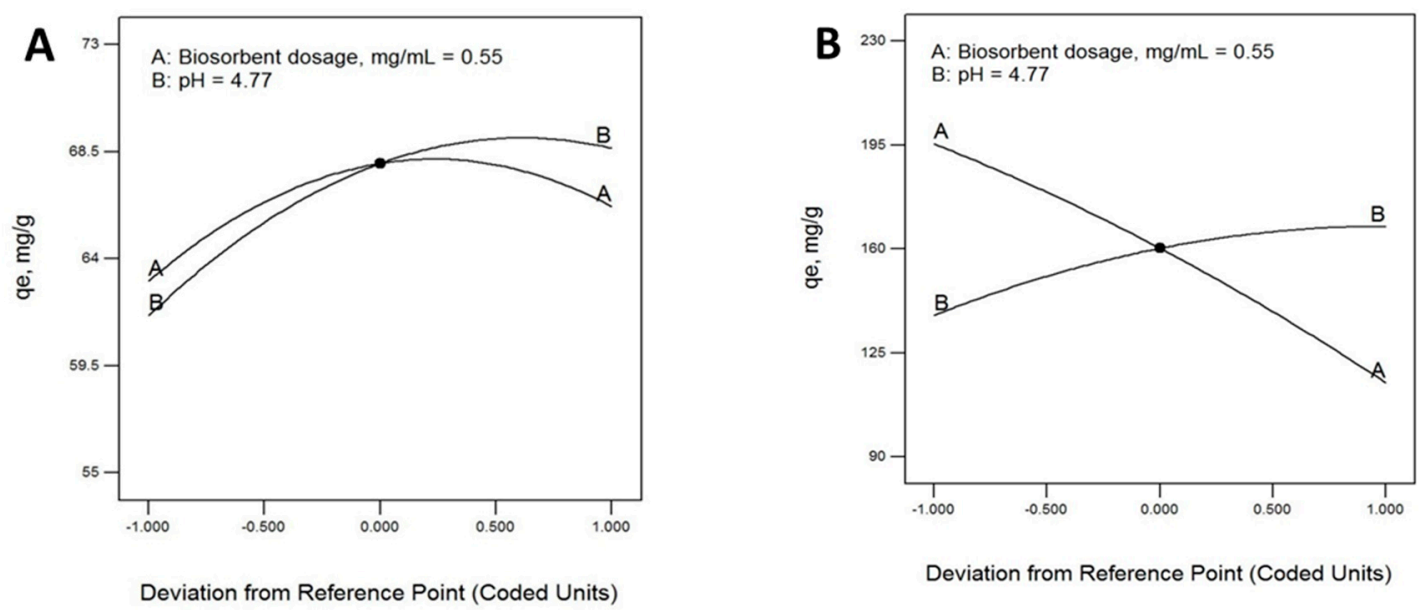

Figure 2. Perturbation plots showing the effect of all investigated factors on lead biosorption capacity by the biomass preparations M3 (A) and VMSM (B) from Botryosphaeria rhodina MAMB-05. 

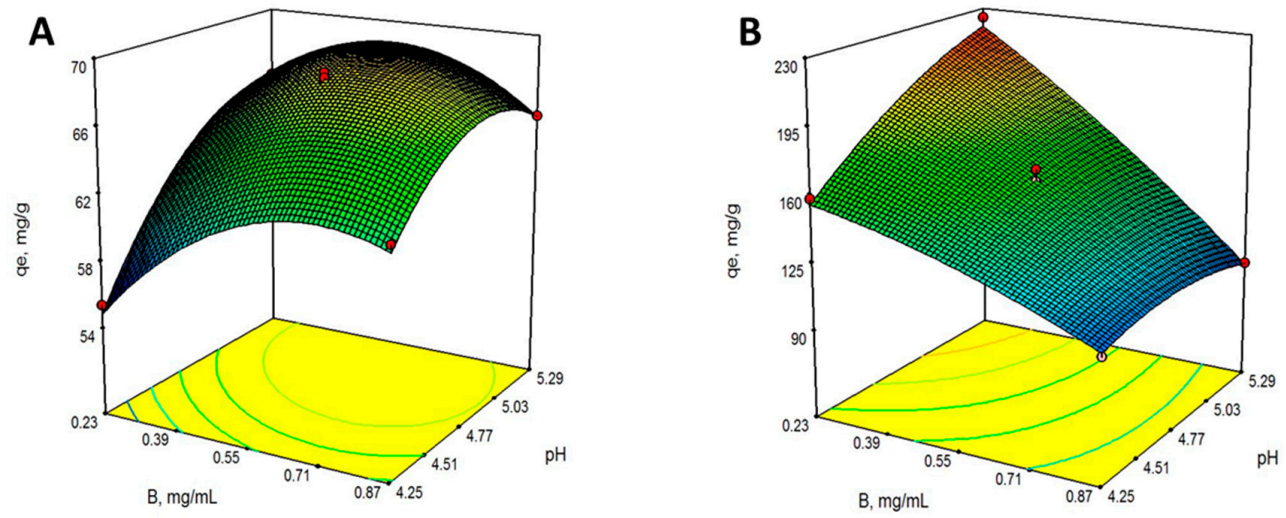

Figure 3. Response surface 3-D plots for $\mathrm{Pb}(\mathrm{II})$ biosorption on biomass M3 (A) and VMSM (B) from Botryosphaeria rhodina MAMB-05. The effect of biosorbent dose (B), $\mathrm{pH}$, and their reciprocal.

\subsection{Biosorption Kinetics of $\mathrm{Pb}(\mathrm{II})$}

The experimental results obtained in the kinetic tests are presented in Figure 4, and show that the biosorption process was fast for both types of biomass preparations. From the nature of the biomass preparations, we deduced that the dominant mechanism would be bioadsorption, and this mechanism markedly depended on the strong contact between the adsorbent and the metal ions of the solution. Despite working under conditions of constant stirring, the characteristics of the biomass did not allow optimum contact until after $5 \mathrm{~h}$. For this reason, the optimum contact time was set at $330 \mathrm{~min}$ for all subsequent tests.

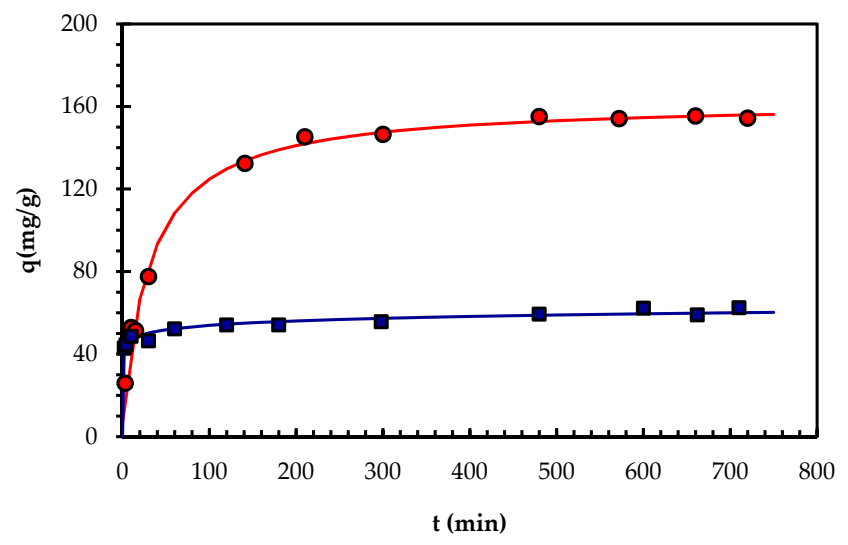

Figure 4. Time profile of $\mathrm{Pb}(\mathrm{II})$ biosorption capacity (q) of biomass preparations $\mathrm{M} 3$ and VMSM from Botryosphaeria rhodina MAMB-05. The symbols (circles: VMSM, squares: M3) are experimental data, whereas the lines correspond to the fitting of the pseudo-second order kinetic for VMSM, and Elovich for M3 models.

The experimental results of the kinetic trials were fitted to three mathematical models as advocated by Vijayaraghvan et al. [21]. Table 5 shows the parameters obtained in the mathematical adjustment considering various boundary conditions [23]). To adjust the experimental data in the mathematical models, linear and non-linear regressions were performed, but the latter offered better adjustments. The results show that for the case of biomass type VMSM, a pseudo-second order is the best model, resulting in a high correlation coefficient for the two integration limits, and with a maximum of 0.994 for the case of: $\mathrm{q}=\mathrm{q}_{\mathrm{i}}$ at $\mathrm{t}=0$ and $\mathrm{q}=\mathrm{q}$ at $\mathrm{t}=\mathrm{t}$. In the case of biomass type M3, the Elovich model was the best fit with a correlation coefficient of 0.987 for the case: $q=0$ at $t=0$ and $q=q$ at $t=t$. The results reported by others $[20,22]$ were consistent with the data obtained in this work. 


\subsection{Biosorption Isotherm for PBPb(II)}

Figure 5 shows the experimental data obtained in the equilibrium tests corresponding to the two types of biomass studied. Table 6 includes the parameters obtained by non-linear regression for the different models evaluated. All mathematical adjustments offered high correlation coefficients, but the model that performed best for both types of biomass was that of Redlich-Peterson with correlation coefficients of 0.998 for VMSM, and 0.990 for M3. From the data obtained, it appears that bioadsorption may be taking place in a complex manner involving monolayer adsorption, as well as non-ideal, reversible, and heterogeneous adsorption.

The maximum biosorption capacity according to Langmuir's model was 403.4 and $96.05 \mathrm{mg}$ $\mathrm{Pb}(\mathrm{II}) / \mathrm{g}$ for the VMSM and M3 biomass preparations, respectively. As shown in Table 4, the results obtained in this work offer maximum biosorption capacities that were above the usual values for other types of microbial biomass biosorbents reported in the scientific literature. The case of the VMSM biomass preparation from $B$. rhodina MAMB-05 is particularly significant, and indicates the potential for its application in the removal of lead, and perhaps other heavy metals too, from contaminated industrial effluents.

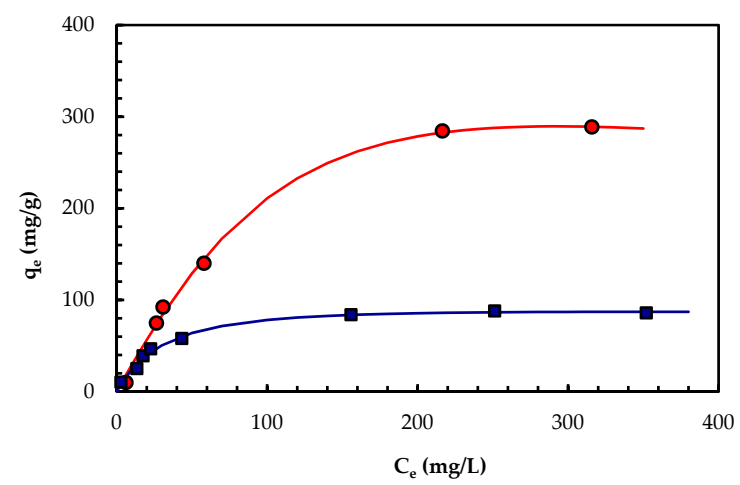

Figure 5. Equilibrium $\mathrm{Pb}$ (II) biosorption capacity (qe) of M3 and VMSM biomass preparations from Botryosphaeria rhodina MAMB-05 versus different $\mathrm{Pb}(\mathrm{II})$ concentrations (Ce). The symbols are experimental data (circles: VMSM, squares: M3), whereas the lines correspond to the Redlich-Peterson isotherms.

Table 4. Maximum $\mathrm{Pb}$ (II) biosorption capacities reported in the scientific literature for different types of biomass preparations.

\begin{tabular}{|c|c|c|}
\hline Biosorbent (Biomass Type) & $\mathrm{q}_{\mathrm{m}}(\mathrm{mg} / \mathrm{g})$ & Reference \\
\hline Penicillium sp. (fungus) & 60.77 & [24] \\
\hline Rhizopus arrhizus (fungus) & 48.79 & [25] \\
\hline Ceratophyllum demursum (aquatic plant) & 44.80 & [26] \\
\hline Activated carbon-Enteromorpha prolifera (green alga) & 146.85 & [27] \\
\hline Bacillus cereus $\mathrm{M}_{16}^{1}$ (bacterium) & 70.42 & [28] \\
\hline Aspergillus niger (fungus) & 34.92 & [29] \\
\hline Dried activated sludge & 131.60 & [30] \\
\hline Caulerpa lentillifera (marine green macroalga) & 28.99 & [31] \\
\hline Cladophora fascicularis (green alga) & 227.70 & [32] \\
\hline Herbaspirillum. chlorophenolicum FA1 (bacterium) & 151.52 & [20] \\
\hline Fucus spiralis (residual biomaterial) & 132 & [33] \\
\hline Bacillus pumilus (bacterium) & 93.24 & [34] \\
\hline Caulerpa lentillifera (marine alga) & 36.67 & [35] \\
\hline Mirabilis jalapa (vegetal leaves) & 38.46 & [36] \\
\hline Escherichia coli (recombinant bacterium) & 108.99 & [37] \\
\hline Labeo rohita (fish scales) & 196.8 & [38] \\
\hline Botrytis cinerea (fungus) & 107.10 & [39] \\
\hline Musa paradisiaca (vegetal stalks) & 13.53 & {$[40]$} \\
\hline Punica geranatum (vegetal leaves) & 18.4 & [41] \\
\hline Klebsiella sp. 3S1(bacterium) & 140.19 & [42] \\
\hline Botryosphaeria rhodina MAMB-05 - VMSM & 403.4 & this study \\
\hline B. rhodina MAMB-05 - M3 & 96.05 & this study \\
\hline
\end{tabular}




\subsection{Chemical and SEM Analysis of the Biomass Preparations from Botryosphaeria rhodina MAMB-05}

The biomass preparations studied here were analyzed by scanning electron microscopy coupled to an EDX detector. Figure 6 show the microphotographs obtained with both biomass preparations. The images show an overview of the fungal biomass samples before $(A, C)$ and after $(B, D)$ the biosorption process, and also the EDX microanalyses obtained in both situations. A large presence of bright particles distributed over the entire surface area can be observed after the biosorption stage with both biomass preparations. In the case of VMSM biomass, these particles were more concentrated on the surface (Figure 6D-inset). Additionally, we can draw another conclusion from the comparison of Figures 6A,C that VMSM biomass has a less compact appearance, and this fact may also explain the better results obtained in the biosorption tests with VMSM; having a larger contact surface that would allow better interaction with the lead ions.
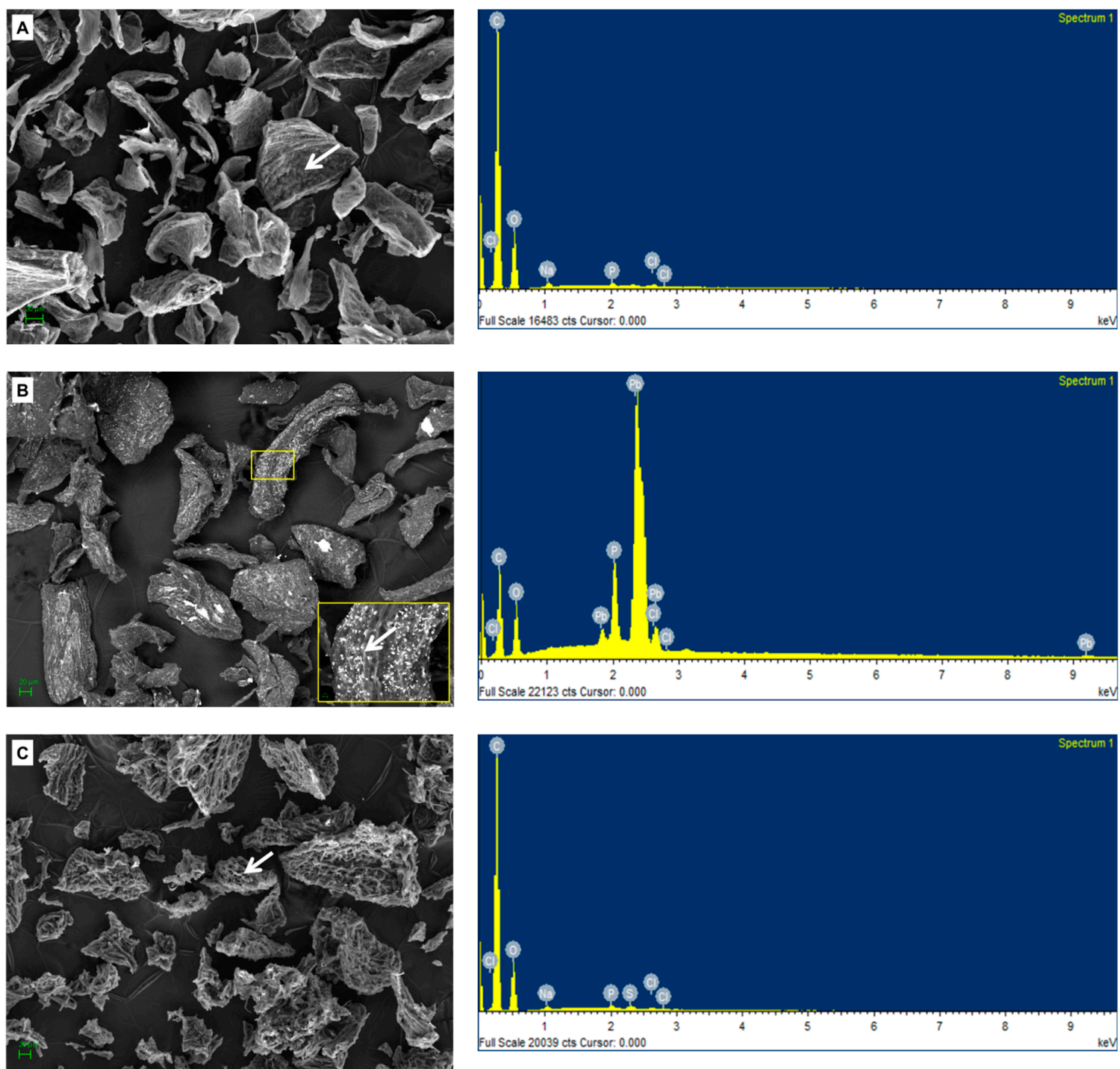

Figure 6. Cont. 

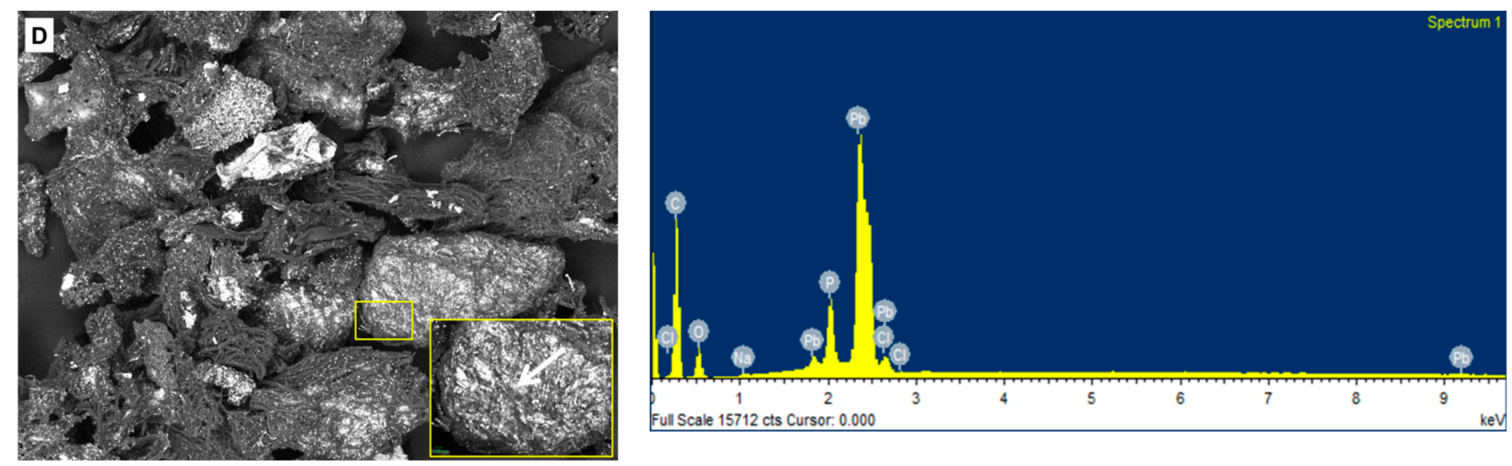

Figure 6. SEM-EDX analysis of M3 and VMSM biomass before $(\mathbf{A}, \mathbf{C})$ and after $(\mathbf{B}, \mathbf{D}) \mathrm{Pb}(\mathrm{II})$ biosorption. The arrows indicate the area where the EDX spectrum was obtained, and show the presence of lead after biosorption.

The EDX spectra demonstrated that the particles on the surface of the biomass were lead precipitates. The results overall indicate that although the two types of biomass preparations were able to sequester $\mathrm{Pb}(\mathrm{II})$ ions, the VMSM biomass was the better biosorbent. The results are consistent with those obtained during experimental trials, and provide graphical evidence that the VMSM biomass showed the best efficacy of the two biosorbents assessed. The data obtained in this work was consistent with the findings presented by others, and demonstrated the potential capacity of this fungal biomass preparation to sequester $\mathrm{Pb}$ (II) ions from aqueous solutions (Table 4).

\section{Materials and Methods}

\subsection{Production of Fungal Biomass}

Botryosphaeria rhodina MAMB-05 was maintained on potato-dextrose agar at $4{ }^{\circ} \mathrm{C}$, and sub-cultured at 3-monthly intervals. The fungus was transferred to agar plates containing glucose $(10 \mathrm{~g} / \mathrm{L})$, minimum salts medium (VMSM) [13] and agar (20 g/L), and left to grow for 4 days at $28^{\circ} \mathrm{C}$. Pre-inoculum was prepared by transferring scrapings of mycelium from the fungal-colonized agar plates to a $250 \mathrm{~mL}$ Erlenmeyer flask containing liquid-medium $(50 \mathrm{~mL})$ comprising glucose $(10 \mathrm{~g} / \mathrm{L})$ and VMSM $(0.16 \mathrm{~mL}$ of a $50 \times$ concentrated stock solution), and left to grow at $28^{\circ} \mathrm{C}$ under shaking conditions (180 rpm) for $48 \mathrm{~h}$. The mycelium was recovered by centrifugation $(1500 \times \mathrm{g} / 15 \mathrm{~min})$, homogenized in isotonic saline solution and inoculum prepared as described by Steluti et al. [43]. Aliquots of $10 \mathrm{~mL}$ inoculum were used to inoculate each of three $2 \mathrm{~L}$ Erlenmeyer flasks containing $800 \mathrm{~mL}$ of nutrient medium.

B. rhodina MAMB-05 was cultivated in Erlenmeyer flasks by submerged fermentation on two types of liquid nutrient medium: (i) basal medium - VMSM [43] comprising sucrose (50 g/L) and $\operatorname{VMSM}(20 \mathrm{~mL} / \mathrm{L})$, and (ii) M3 comprising sucrose (50 g), $\mathrm{NaNO}_{3}(3 \mathrm{~g}), \mathrm{KH}_{2} \mathrm{PO}_{4}(1 \mathrm{~g}), \mathrm{MgSO}_{4} \cdot 7 \mathrm{H}_{2} \mathrm{O}$ $(0.5 \mathrm{~g}), \mathrm{KCl}(0.5)$, and yeast extract (Oxoid, UK; $1 \mathrm{~g})$ per liter of distilled water [14]. The initial $\mathrm{pH}$ of both media was adjusted to 5.8 . Fermentation was carried out under shaking conditions (180 rpm) for $72 \mathrm{~h}$ at $28^{\circ} \mathrm{C}$.

The fungal cultures were harvested by centrifugation $(1500 \times \mathrm{g} / 30 \mathrm{~min})$, and the mycelium recovered. Distilled water $(100 \mathrm{~mL})$ was added to the fungal biomass and the slurry autoclaved at $121{ }^{\circ} \mathrm{C}$ for $20 \mathrm{~min}$. This was followed by lyophilization, and the dried biomass was powdered in a blender, and stored at ambient temperature until required. The 2 types of fungal biomass preparations (designated VMSM and M3) were evaluated for biosorption. 


\subsection{Fungal Biomass Characterization: FT-IR Analysis}

In order to identify the presence of functional groups that are potentially involved in the biosorption phenomena, the fungal biomass preparations were analyzed by Fourier Transform Infrared Spectroscopy (FT-IR). Samples of biomass before and after the biosorption process were taken for FT-IR analysis, and subsequently lyophilized and analyzed by attenuated total reflectance (ATR) in a Spectrometer VERTEX 70 (Bruker Corporation, Billerica, Massachusetts, United States), working in the range between 4000 and $400 \mathrm{~cm}^{-1}$.

\subsection{Optimizing Conditions for Biosorption of $\mathrm{Pb}(\mathrm{II})$}

The factors involved in the biosorption process were analyzed through a Rotatable Central Composite Design (RCCD) and then analyzed by RSM. The assays were performed using a $\mathrm{Pb}$ (II) solution $(100 \mathrm{mg} / \mathrm{L})$ under shaking conditions $(200 \mathrm{rpm})$ for $24 \mathrm{~h}$ at $27^{\circ} \mathrm{C}$. Factors analyzed were biomass concentration within the range of $0.23-1.00 \mathrm{~g} / \mathrm{L}$ for each of the 2 types of biomass preparations, and $\mathrm{pH}$ ranging from 4.25-5.51. The working solution was prepared with $\mathrm{Pb}\left(\mathrm{NO}_{3}\right)_{2}$ in distilled water, and the $\mathrm{pH}$ was adjusted with $0.1 \mathrm{M} \mathrm{NaOH}$ or $0.1 \mathrm{M} \mathrm{HNO}_{3}$ solutions. The tests were performed in duplicate in $100 \mathrm{~mL}$ flasks with a working volume of $50 \mathrm{~mL}$ in an orbital shaker (INFORS HT, Ecotron, Infors AG, Bottmingen, Switzerland). After the tests were completed, the samples were filtered through polyethersulfone filters $(0.22 \mu \mathrm{m})$, and the filtrates analyzed for elemental lead $(\mathrm{Pb})$ by atomic absorption spectrometry (AAS) using an AAnalyst 800 instrument (Perkin Elmer, Midland, ON, Canada).

The biosorption capacity per unit of dry mass was determined according to Equation (3):

$$
q=\frac{(C i-C f) V}{m}
$$

where $C i$ is the initial metal concentration; $C f$ is the final metal concentration; $V$ is the solution volume (50 $\mathrm{mL})$; and $\mathrm{m}$ is the weight of the biosorbent (g, dry basis).

\subsection{Biosorption Kinetics}

Kinetic tests were carried out to obtain the optimal time of operation in the biosorption process from an initial metallic solution of $100 \mathrm{mg} / \mathrm{L}$. The tests were performed with working volumes of 50 $\mathrm{mL}$ of $\mathrm{Pb}$ (II) solution in $100 \mathrm{~mL}$ flasks at $27^{\circ} \mathrm{C}$ and shaken at $200 \mathrm{rpm}$. The tests were performed in duplicate for each contact time examined over a period ranging from 0 to $720 \mathrm{~min}$. Concentration of dry biomass and $\mathrm{pH}$ were selected from the conditions optimized for lead biosorption for each type of biomass preparation used: $0.23 \mathrm{~g} / \mathrm{L}, \mathrm{pH}: 5.3$ for type VMSM; and $0.60 \mathrm{~g} / \mathrm{L}, \mathrm{pH}: 5.0$ for type M3. The samples were analyzed as specified in Section 3.3.

Several kinetic models were considered to adjust the experimental data. The models included pseudo-first order or Lagergren [44], pseudo-second order [23], and Elovich [45]. The kinetic models were tested as outlined in Table 5 using non-linear regression. The software program used was SPSS Statistics version 19 (SPSS Inc., Chicago, IL, USA). When using the models, the adsorption process was assumed to be controlled by chemical reactions and not by diffusion. 
Table 5. Kinetic models tested and kinetic parameters obtained for the biosorption of $\mathrm{Pb}$ (II) by the two types of biomass from Botryosphaeria rhodina MAMB-05. Integrated equations and boundary conditions considered.

\begin{tabular}{|c|c|c|c|c|}
\hline & & \multirow[t]{2}{*}{ Parameter } & \multicolumn{2}{|c|}{ Biomass Preparation } \\
\hline & & & VMSM & M3 \\
\hline \multicolumn{5}{|c|}{ Pseudo-first order, or Lagergren [44] } \\
\hline \multirow{9}{*}{$\frac{\mathrm{dq}}{\mathrm{dt}}=\mathrm{k}_{1}\left(\mathrm{q}_{\mathrm{e}}-\mathrm{q}\right)$} & \multirow{2}{*}{$\mathrm{q}=0$ at $\mathrm{t}=0$ and $\mathrm{q}=\mathrm{q}$ para $\mathrm{t}=\mathrm{t}$} & $\mathrm{q}_{\mathrm{e}}$ & 149.4 & 55.059 \\
\hline & & $\mathrm{k}_{1}$ & 0.02864 & 0.6216 \\
\hline & \multirow{2}{*}{$q=q_{e}\left(1-e^{-k_{1} t}\right)$} & $\mathrm{r}^{2}$ & 0.977 & 0.899 \\
\hline & & $\Sigma\left(\mathrm{q}-\mathrm{q}_{\mathrm{cal}}\right)^{2}$ & 847 & 317 \\
\hline & \multirow[b]{2}{*}{$\mathrm{q}=\mathrm{q}_{\mathrm{i}}$ at $\mathrm{t}=0$ and $\mathrm{q}=\mathrm{q}$ at $\mathrm{t}=\mathrm{t}$} & $\mathrm{q}_{\mathrm{e}}$ & 150.4 & 55.07 \\
\hline & & $\mathrm{q}_{\mathrm{i}}$ & 12.69 & 0.5672 \\
\hline & \multirow{3}{*}{$q=q_{e}\left(1-e^{-k_{1} t}\right)+q_{i} e^{-k_{1} t}$} & $\mathrm{k}_{1}$ & 0.02211 & 0.6156 \\
\hline & & $\mathrm{r}^{2}$ & 0.984 & 0.899 \\
\hline & & $\Sigma\left(\mathrm{q}-\mathrm{q}_{\mathrm{cal}}\right)^{2}$ & 595 & 316 \\
\hline \multicolumn{5}{|l|}{ Pseudo-second order [23] } \\
\hline \multirow{9}{*}{$\frac{\mathrm{dq}}{\mathrm{dt}}=\mathrm{k}_{2}\left(\mathrm{q}_{\mathrm{e}}-\mathrm{q}\right)^{2}$} & \multirow[t]{2}{*}{$\mathrm{q}=0$ at $\mathrm{t}=0$ and $\mathrm{q}=\mathrm{q}$ at $\mathrm{t}=\mathrm{t}$} & $\mathrm{q}_{\mathrm{e}}$ & 161.2 & 56.31 \\
\hline & & $\mathrm{k}_{2}$ & $2.246 \times 10^{-4}$ & 0.02031 \\
\hline & \multirow{2}{*}{$q=\frac{t}{\left(\frac{1}{2}+\frac{t}{2}\right)}$} & $\mathrm{r}^{2}$ & 0.992 & 0.934 \\
\hline & & $\Sigma\left(\mathrm{q}-\mathrm{q}_{\mathrm{cal}}\right)^{2}$ & 295 & 207 \\
\hline & \multirow[b]{2}{*}{$\mathrm{q}=\mathrm{q}_{\mathrm{i}}$ at $\mathrm{t}=0$ and $\mathrm{q}=\mathrm{q}$ at $\mathrm{t}=\mathrm{t}$} & $\mathrm{q}_{\mathrm{e}}$ & 162.5 & 56.32 \\
\hline & & $\mathrm{q}_{\mathrm{i}}$ & 6.616 & 0.2600 \\
\hline & \multirow{3}{*}{$q=q_{e}-\left(\frac{\left(q_{e}-q_{i}\right)}{\left(1+k_{2} t\left(q_{e}-q_{i}\right)\right)}\right)$} & $k_{2}$ & $2.008 \times 10^{-4}$ & 0.02026 \\
\hline & & $\mathrm{r}^{2}$ & 0.994 & 0.934 \\
\hline & & $\Sigma\left(\mathrm{q}-\mathrm{q}_{\mathrm{cal}}\right)^{2}$ & 229 & 207 \\
\hline \multicolumn{5}{|l|}{ Elovich [45] } \\
\hline \multirow{9}{*}{$\frac{d q}{d t}=a e^{-b q}$} & \multirow{2}{*}{$\mathrm{q}=0$ at $\mathrm{t}=0$ and $\mathrm{q}=\mathrm{q}$ at $\mathrm{t}=\mathrm{t}$} & a & 15.66 & $1.026 \times 10^{6}$ \\
\hline & & $\mathrm{b}$ & 0.03659 & 0.32098 \\
\hline & \multirow{2}{*}{$q=\frac{1}{b} \ln (1+a b t)$} & $\mathrm{r}^{2}$ & 0.982 & 0.987 \\
\hline & & $\Sigma\left(\mathrm{q}-\mathrm{q}_{\mathrm{cal}}\right)^{2}$ & 666 & 39 \\
\hline & \multirow[b]{2}{*}{$\mathrm{q}=\mathrm{q}_{\mathrm{i}}$ at $\mathrm{t}=0$ and $\mathrm{q}=\mathrm{q}$ at $\mathrm{t}=\mathrm{t}$} & a & 15.81 & $1.026 \times 10^{6}$ \\
\hline & & $\mathrm{b}$ & 0.03667 & 0.3210 \\
\hline & \multirow{3}{*}{$q=\frac{1}{b} \ln \left(a b t+e^{b q_{i}}\right)$} & $\mathrm{q}_{\mathrm{i}}$ & -1.210 & $7.136 \times 10^{-9}$ \\
\hline & & $\mathrm{r}^{2}$ & 0.982 & 0.987 \\
\hline & & $\Sigma\left(\mathrm{q}-\mathrm{q}_{\mathrm{cal}}\right)^{2}$ & 665 & 39 \\
\hline
\end{tabular}




\subsection{Equilibrium Study}

The equilibrium tests were performed as described in Section 3.4, but in this case the contact time was set to $330 \mathrm{~min}$, and different lead concentrations were tested that ranged from 10 to $400 \mathrm{mg} / \mathrm{L}$ of $\mathrm{Pb}(\mathrm{II})$.

Four models: Langmuir [46], Freundlich [47], Sips [48], and Redlich-Peterson [49], were considered (see Table 6) and used to adjust the experimental data. The Langmuir model assumes monolayer adsorption according to a homogenous adsorbent. The Freundlich model is an empirical model that assumes that the adsorbent increases its adsorption surface when the concentration of adsorbent increases, and then it can be applied to multilayers and heterogeneous surfaces. The Sips model takes into account the starting principles of Langmuir and Freundlich and can be used in a wide range of concentrations. Finally, the Redlich-Peterson model is an empirical model that can also be used in a wide range of concentrations, and considers that when $\beta$ is equal to one, the model obeys the Langmuir isotherm, and when $\beta$ is equal to zero, Henry's law is obeyed. The software package SPSS version 19.0 was also used to fit the experimental data.

Table 6. Isotherm models and biosorption equilibrium parameters for the different isotherm models tested for the biosorption of $\mathrm{Pb}(\mathrm{II})$ by the two types of biomass preparations from Botryosphaeria rhodina MAMB-05.

\begin{tabular}{|c|c|c|c|c|}
\hline \multirow{2}{*}{ Model } & \multirow{2}{*}{ Equation } & \multirow{2}{*}{ Parameter } & \multicolumn{2}{|c|}{ Biomass Preparation } \\
\hline & & & VMSM & M3 \\
\hline \multirow[t]{4}{*}{ Langmuir [46] } & \multirow{4}{*}{$\mathrm{q}_{\mathrm{e}}=\frac{\mathrm{q}_{\mathrm{m}} \mathrm{bC}_{\mathrm{e}}}{1+\mathrm{bC}_{\mathrm{e}}}$} & $\mathrm{q}_{\mathrm{m}}$ & 403.4 & 96.05 \\
\hline & & B & $9.252 \times 10^{-3}$ & 0.03575 \\
\hline & & $r^{2}$ & 0.992 & 0.988 \\
\hline & & $\Sigma\left(\mathrm{q}-\mathrm{q}_{\mathrm{cal}}\right)^{2}$ & 549 & 75 \\
\hline \multirow[t]{4}{*}{ Freundlich [47] } & \multirow{4}{*}{$\mathrm{q}_{\mathrm{e}}=\mathrm{K}_{\mathrm{F}} \mathrm{C}_{\mathrm{e}}^{1 / \mathrm{n}}$} & $\mathrm{K}_{\mathrm{F}}$ & 14.485 & 15.34 \\
\hline & & $\mathrm{N}$ & 1.874 & 3.202 \\
\hline & & $\mathrm{r}^{2}$ & 0.963 & 0.915 \\
\hline & & $\Sigma\left(\mathrm{q}-\mathrm{q}_{\mathrm{cal}}\right)^{2}$ & 2473 & 517 \\
\hline \multirow[t]{5}{*}{ Sips [48] } & \multirow{5}{*}{$\mathrm{q}_{\mathrm{e}}=\frac{\mathrm{K}_{\mathrm{s}} \mathrm{C}_{\mathrm{e}}^{1 / \mathrm{n}}}{1+\mathrm{a}_{\mathrm{s}} \mathrm{C}_{\mathrm{e}}^{1 / \mathrm{n}}}$} & $\mathrm{K}_{\mathrm{s}}$ & 1.219 & 2.316 \\
\hline & & $a_{\mathrm{s}}$ & $3.640 \times 10^{-3}$ & $2.502 \times 10^{-2}$ \\
\hline & & $\mathrm{N}$ & 0.7541 & 0.8776 \\
\hline & & $\mathrm{r}^{2}$ & 0.996 & 0.989 \\
\hline & & $\Sigma\left(\mathrm{q}-\mathrm{q}_{\mathrm{cal}}\right)^{2}$ & 267 & 68 \\
\hline \multirow[t]{5}{*}{ Redlich-Peterson [49] } & \multirow{5}{*}{$\mathrm{q}_{\mathrm{e}}=\frac{\mathrm{K}_{\mathrm{RP}} \mathrm{C}_{\mathrm{e}}}{1+\mathrm{a}_{\mathrm{RP}} \mathrm{C}_{\mathrm{e}}^{\beta}}$} & $\mathrm{K}_{\mathrm{RP}}$ & 2.922 & 2.910 \\
\hline & & $a_{R P}$ & $3.625 \times 10^{-4}$ & $1.782 \times 10^{-2}$ \\
\hline & & $\mathrm{B}$ & 1.513 & 1.092 \\
\hline & & $r^{2}$ & 0.998 & 0.990 \\
\hline & & $\Sigma\left(\mathrm{q}-\mathrm{q}_{\mathrm{cal}}\right)^{2}$ & 153 & 60 \\
\hline
\end{tabular}

$\mathrm{q}_{\mathrm{e}}$ : biosorption capacity $(\mathrm{mg} / \mathrm{g})$ at equilibrium; $\mathrm{q}_{\mathrm{m}}$ : maximum biosorption capacity $(\mathrm{mg} / \mathrm{g}) ; \mathrm{b}$ : Langmuir biosorption equilibrium constant $(\mathrm{L} / \mathrm{mg}) ; \mathrm{C}_{\mathrm{e}}$ : equilibrium concentrations of metal $(\mathrm{mg} / \mathrm{L}) ; \mathrm{K}_{\mathrm{F}}$ : characteristic constant related to the biosorption capacity; $\mathrm{n}$ : characteristic constant related to the biosorption intensity; $\mathrm{K}_{\mathrm{s}}$ and $\mathrm{a}_{\mathrm{s}}$ : Sips isotherm parameters; $K_{R P}$, $a_{R P}$ and $\beta$ : Redlich-Peterson parameters; $r^{2}$ is the correlation coefficient; $\Sigma\left(q-q_{c a l}\right)^{2}$ is the sum of the errors squared.

\subsection{Field Emission-Scanning Electron Microscopy-Energy Dispersive X-Ray Analysis}

In order to understand the topography of the fungal biomass, field emission-scanning electron microscopy (FE-SEM, MERLIN of Carl Zeiss, Göttingen, Germany) coupled to an EDX detector was used. This technique also makes it possible to identify the presence of metal precipitates on the surface of the adsorbent. Biomass samples were taken before and after the biosorption trials, and prepared as described by Muñoz et al. [50]. 


\section{Conclusions}

The results obtained in this work demonstrate that the reused biomass from the filamentous fungus, Botryosphaeria rhodina MAMB-05, is an effective biosorbent of $\mathrm{Pb}(\mathrm{II})$. The two types of biomass preparations evaluated gave good results in removing lead ions from aqueous solutions at a concentration of $100 \mathrm{mg} / \mathrm{L}$, with a maximum biosorption capacity according to the Langmuir model of $96.05 \mathrm{mg} / \mathrm{g}$ for the M3 type, and $403.4 \mathrm{mg} / \mathrm{g}$ for VMSM. The characterization of the biomass and its subsequent analysis by FT-IR identified the involvement of many functional groups in the bioadsorption process. In the VMSM type biomass, the functional groups derived from carboxyl groups (hydroxyl and carbonyl) had a strong implication and could indicate the presence of some type of bidentate chelation with the $\mathrm{Pb}(\mathrm{II})$ ions. Likewise, the intervention in the process of bioadsorption of methyl and methylene groups together with groups linked to amides type I and II also seems to be proved. In the M3 biomass there was a lower involvement of functional groups but the participation of methyl and carbonyl groups, and amides type I and II was tested. The FE-SEM-EDX analysis also identified that the VMSM subtype had a less compact appearance and therefore a greater specific surface that could influence a better exposure of the different functional groups.

Author Contributions: Conceptualization, A.J.M., F.E., E.R. and E.C.; Data curation, A.J.M. and F.E.; Formal analysis, A.J.M. and F.E.; Investigation, A.J.M., A.M.B.-D. and R.F.H.D.; Methodology, A.J.M., F.E., E.R. and E.C.; Resources, A.M.B.-D. and R.F.H.D.; Software, A.J.M. and F.E.; Supervision, F.E. and E.C.; Validation, A.J.M. and F.E.; Visualization, A.J.M., F.E. and E.R.; Writing—original draft, A.J.M. and F.E.; Writing-review \& editing, E.R., A.M.B.-D., R.F.H.D. and E.C.

Funding: This research received no external funding.

Acknowledgments: This research did not receive any specific grant from funding agencies in the public, commercial, or not-for-profit sectors.

Conflicts of Interest: The authors declare no conflict of interest.

\section{References}

1. Binkowski, L.J. The influence of environmental conditions on lead transfer from spent gunshot to sediments and water: Other routes for Pb poisoning. Chemosphere 2017, 187, 330-337. [CrossRef] [PubMed]

2. Laidlaw, M.A.S.; Filippelli, G.M.; Brown, S.; Paz-Ferreiro, J.; Reichman, S.M.; Netherway, P.; Truskewycz, A.; Ball, A.S.; Mielke, H.W. Case studies and evidence-based approaches to addressing urban soil lead contamination. Appl. Geochem. 2017, 83, 14-30. [CrossRef]

3. Ministerio de Agricultura y Pesca, Alimentación y Medio Ambiente, Gobierno de España. Registro Estatal de Emisiones y Fuentes Contaminantes: Emisiones por Sustancias Contaminantes. 2017. Available online: http://www.prtr-es.es (accessed on 10 September 2019).

4. Tirima, S.; Bartrem, C.; Lindern, I.V.; Braun, M.V.; Lind, D.; Anka, S.M.; Abdullahi, A. Food contamination as a pathway for lead exposure in children during the 2010-2013 lead poisoning epidemic in Zamfara. Nigeria. J. Environ. Sci. 2017, 67, 260-272. [CrossRef] [PubMed]

5. Gadd, G.M. Biosorption: Critical review of scientific rationale, environmental importance and significance for pollution treatment. J. Chem. Technol. Biotechnol. 2009, 84, 13-28. [CrossRef]

6. Morosanu, I.; Teodosiu, C.; Padararu, C.; Ibanescu, D.; Tofan, L. Biosorption of lead ions from aqueous effluents by rapeseed biomass. New Biotechnol. 2017, 39, 110-124. [CrossRef] [PubMed]

7. Fomina, M.; Gadd, G.M. Biosorption: Current perspectives on concept: Definition and application. Bioresour. Technol. 2014, 160, 3-14. [CrossRef] [PubMed]

8. Barros, O.; Costa, L.; Costa, F.; Lago, A.; Rocha, V.; Vipotnik, Z.; Silva, B.; Tavares, T. Recovery of rare earth elements from wastewater towards a circular economy. Molecules 2019, 24, 1005. [CrossRef] [PubMed]

9. Dekker, R.F.H.; Barbosa, A.M. Effect of aeration and veratryl alcohol on the production of two laccases by the ascomycete Botryosphaeria sp. Enzym. Microb. Technol. 2001, 28, 81-88. [CrossRef]

10. Barbosa, A.M.; Steluti, R.M.; Dekker, R.F.H.; Cardoso, M.S.; Corradi da Silva, M.L. Structural characterization of Botryosphaeran: A $(1 \rightarrow 3 ; 1 \rightarrow 6)-\beta$-D-glucan produced by the ascomyceteous fungus, Botryosphaeria sp. Carbohydr. Res. 2003, 338, 1691-1698. [CrossRef] 
11. Dekker, R.F.H.; Barbosa, A.M.; Sargent, K. The effect of lignin-related compounds on growth and production of laccases by the ligninolytic ascomycete, Botryosphaeria sp. Enzym. Microb. Technol. 2002, 30, 374-380. [CrossRef]

12. Giese, E.C.; Dekker, R.F.H.; Barbosa-Dekker, A.M. Biosorption of lanthanum and samarium by viable and autoclaved mycelium of Botryosphaeria rhodina MAMB-05. Biotechnol. Prog. 2019, 35, e2783. [CrossRef] [PubMed]

13. Vogel, H.J. A Convenient Growth Medium for Neurospora crassa. Microb. Genet. Bull. 1956, 13, $42-43$.

14. Crognale, S.; Bruno, M.; Fidaleo, M.; Moresi, M.; Petruccioli, M. Production of $\beta$-glucan and related glucan-hydrolases by Botryosphaeria rhodina. J. Appl. Microbiol. 2007, 102, 860-871. [CrossRef] [PubMed]

15. Corradi da Silva, M.L.; Fukuda, E.K.; Vasconcelos, A.F.D.; Dekker, R.F.H.; Matias, A.C.; Monteiro, N.K.; Cardoso, M.S.; Barbosa, A.M.; Silveira, J.L.M.; Sassaki, G.L.; et al. Structural characterization of the cell wall D-glucans isolated from the mycelium of Botryosphaeria rhodina MAMB-05. Carbohydr. Res. 2008, 343, 793-798. [CrossRef] [PubMed]

16. Miller, L.M.; Dumas, P. From structure to cellular mechanism with infrared microspectroscopy. Curr. Opin. Struct. Biol. 2010, 20, 649-656. [CrossRef] [PubMed]

17. Wang, N.; Jin, R.-N.; Omer, A.M.; Ouyang, X.-K. Adsorption of Pb(II) from fish sauce using carboxylated cellulose nanocrystal: Isotherm, kinetics, and thermodynamic studies. Int. J. Biol. Macromol. 2017, 102, 232-240. [CrossRef] [PubMed]

18. Wang, Y.; Zhou, Q.; Li, B.; Liu, B.; Wu, G.; Ibrahim, M.; Xie, G.; Li, H.; Sun, G. Differentiation in MALDI-TOF MS and FTIR spectra between two closely related species Acidovorax oryzae and Acidovorax citrulli. BMC Microbiol. 2012, 12, 182. [CrossRef]

19. Wang, N.; Ouyang, X.-K.; Yang, L.-Y.; Omer, A.M. Fabrication of a magnetic cellulose nanocrystal/metal-organic framework composite for removal of $\mathrm{Pb}(\mathrm{II})$ from water. ACS Sustain. Chem. Eng. 2017, 5, 10447-10458. [CrossRef]

20. Li, X.; Xu, H.; Gao, B.; Shi, X.; Sun, Y.; Wu, J. Efficient biosorption of $\mathrm{Pb}(\mathrm{II})$ from aqueous solutions by a PAH-degrading strain Herbaspirillum chlorophenolicum FA1. J. Ind. Eng. Chem. 2018, 57, 64-71. [CrossRef]

21. Vijayaraghvan, K.; Yun, Y.S. Bacterial biosorbents and biosorption. Biotechnol. Adv. 2008, 26, $266-291$. [CrossRef]

22. Kirova, G.; Velkova, Z.; Stoytcheva, M.; Hristova, Y.; Iliev, I.; Gochev, V. Biosorption of Pb(II) ions from aqueous solutions by waste biomass of Streptomyces fradiae pretreated with $\mathrm{NaOH}$. Biotechnol. Biotechnol. Equip. 2015, 29, 689-695. [CrossRef]

23. Ho, Y.S.; Wase, D.A.J.; Forster, C.F. Kinetic studies of competitive heavy metal adsorption by sphagnum peat. Environ. Technol. 1996, 17, 71-77. [CrossRef]

24. Ezzouhri, L.; Ruiz, E.; Castro, E.; Moya, M.; Espínola, F.; Cherrad, L.; Er-Raioui, H.; Lairini, K. Mechanisms of lead uptake by fungal biomass isolated from heavy metals habitats. Afinidad 2010, 67, 39-44.

25. Sag, Y.; Yalc,uk, A.; Kutsal, T. Mono and multi-component biosorption of heavy metal ions on Rhizopus arrhizus in a CFST. Process. Biochem. 2000, 35, 787-799. [CrossRef]

26. Keskinkan, O.; Goksu, M.Z.L.; Basibuyuk, M.; Forster, C.F. Heavy metal adsorption properties of a submerged aquatic plant (Ceratophyllum demersum). Bioresour. Technol. 2004, 92, 197-200. [CrossRef] [PubMed]

27. Li, Y.; Du, Q.; Wang, X.; Zhang, P.; Wang, D.; Wang, Z.; Xia, Y. Removal of lead from aqueous solution by activated carbon prepared from Enteromorpha prolifera by zinc chloride activation. J. Hazard. Mater. 2010, 183, 583-589. [CrossRef] [PubMed]

28. Ray, L.; Paul, S.; Bera, D.; Chattopadhyay, P. Bioaccumulation of $\mathrm{Pb}$ (II) from aqueous solutions by Bacillus cereus $M^{1}{ }_{16}$. J. Hazard. Subst. Res. 2006, 5, 1 .

29. Dursun, A.Y. A comparative study on determination of the equilibrium, kinetic and thermodynamic parameters of biosorption of copper(II) and lead(II) ions onto pretreated Aspergillus niger. Biochem. Eng. J. 2006, 28, 187-195. [CrossRef]

30. Wang, X.J.; Xia, S.Q.; Chen, L.; Zhao, J.F.; Chovelon, J.M.; Nicole, J.R. Biosorption of cadmium(II) and lead(II) ions from aqueous solutions onto dried activated sludge. J. Environ. Sci. 2006, 18, 840-844. [CrossRef]

31. Pavasant, P.; Apiratikul, R.; Sungkhum, V.; Suthiparinyanont, P.; Wattanachira, S.; Marhaba, T.F. Biosorption of $\mathrm{Cu}^{2+}, \mathrm{Cd}^{2+}, \mathrm{Pb}^{2+}$, and $\mathrm{Zn}^{2+}$ using dried marine green macroalga Caulerpa lentillifera. Bioresour. Technol. 2006, 97, 2321-2329. [CrossRef] 
32. Deng, L.; Su, Y.; Su, H.; Wang, X.; Zhu, X. Sorption and desorption of lead (II) from wastewater by green algae Cladophora fascicularis. J. Hazard. Mater. 2007, 143, 220-225. [CrossRef] [PubMed]

33. Filote, C.; Volf, I.; Santos, S.C.R.; Botelho, C.M.S. Bioadsorptive removal of $\mathrm{Pb}$ (II) from aqueous solution by the biorefinery waste of Fucus spiralis. Sci Total Environ. 2019, 648, 1201-1209. [CrossRef] [PubMed]

34. Pepi, M.; Borra, M.; Tamburrino, S.; Saggiomo, M.; Viola, A.; Biffali, E.; Balestra, C.; Sprovieri, M.; Casotti, R. A Bacillus sp. isolated from sediments of the Sarno River mouth, Gulf of Naples (Italy) produces a biofilm biosorbing Pb(II). Sci. Total Environ. 2016, 562, 588-595. [CrossRef] [PubMed]

35. Apiratikul, R.; Madacha, V.; Pavasant, P. Kinetic and mass transfer analyses of metal biosorption by Caulerpa lentillifera. Desalination 2011, 278, 303-311. [CrossRef]

36. Begum, S.A.S.; Tharakeswar, Y.; Kalyan, Y.; Naidu, G.R. Biosorption of Cd(II), Cr(VI) \& Pb(II) from aqueous solution using Mirabilis jalapa as adsorbent. J. Encapsulation Adsorpt. Sci. 2015, 5, 93-104.

37. Nguyen, T.T.L.; Lee, H.R.; Hong, S.H.; Jang, J.R.; Choe, W.-S.; Yoo, I.K. Selective lead adsorption by recombinant Escherichia coli displaying a lead-binding peptide. Appl. Biochem. Biotechnol. 2013, 169, 1188-1196. [CrossRef] [PubMed]

38. Nadeem, R.; Ansari, T.M.; Khalid, A.M. Fourier Transform Infrared Spectroscopic characterization and optimization of $\mathrm{Pb}(\mathrm{II})$ biosorption by fish (Labeo rohita) scales. J. Hazard. Mater. 2008, 156, 64-73. [CrossRef]

39. Akar, T.; Tunali, S.; Kiran, I. Botrytis cinerea as a new fungal biosorbent for removal of $\mathrm{Pb}(\mathrm{II})$ from aqueous solutions. Biochem. Eng. J. 2005, 25, 227-235. [CrossRef]

40. Ogunleye, O.O.; Ajala, M.A.; Agarry, S.E. Evaluation of biosorptive capacity of banana (Musa paradisiaca) stalk for lead(II) removal from aqueous solution. J. Environ. Prot. 2014, 5, 1451-1465. [CrossRef]

41. Salehi, P.; Asghari, B.; Mohammadi, F. Biosorption of $\mathrm{Ni}(\mathrm{II}), \mathrm{Cu}(\mathrm{II})$ and $\mathrm{Pb}(\mathrm{II})$ by Punica geranatum from aqueous solutions. J. Water Resour. Prot. 2010, 2, 701-705. [CrossRef]

42. Muñoz, A.J.; Espínola, F.; Moya, M.; Ruiz, E. Biosorption of $\mathrm{Pb}(\mathrm{II})$ ions by Klebsiella sp. $3 \mathrm{~S} 1$ isolated from a wastewater treatment plant: Kinetics and mechanisms studies. BioMed Res. Int. 2015. [CrossRef]

43. Steluti, R.M.; Giese, E.C.; Pigato, M.M.; Sumiya, A.F.G.; Covizzi, L.G.; Job, A.E.; Cardoso, M.S.; Corradi da Silva, M.L.; Dekker, R.F.H.; Barbosa, A.M. Comparison of Botryosphaeran production by the ascomyceteous fungus Botryosphaeria sp., grown on different carbohydrate carbon sources, and their partial structural features. J. Basic Microbiol. 2004, 44, 480-486. [CrossRef] [PubMed]

44. Febrianto, J.; Kosasih, A.N.; Sunarso, J.; Ju, Y.H.; Indraswati, N.; Ismadji, S. Equilibrium and kinetic studies in adsorption of heavy metals using biosorbent: A summary of recent studies. J. Hazard. Mater. 2009, 162, 616-645. [CrossRef] [PubMed]

45. Cheung, C.W.; Porter, J.F.; McKay, G. Sorption kinetic analysis for the removal of cadmium ions from effluents using bone char. Water Res. 2001, 35, 605-612. [CrossRef]

46. Langmuir, I. Adsorption of gases on plane surface of glass, mica and platinum. J. Am. Chem. Soc. 1918, 40, 1361-1403. [CrossRef]

47. Freundlich, H. Adsorption in solutions. Phys. Chem. 1906, 57, 384-410.

48. Sips, R. Combined form of Langmuir and Freundlich equations. J. Chem. Phys. 1948, 16, 490-549. [CrossRef]

49. Redlich, O.; Peterson, D.L. A useful adsorption isotherm. J. Phys. Chem. C 1959, 63, 1024-1039. [CrossRef]

50. Muñoz, A.J.; Espínola, F.; Ruiz, E. Biosorption of Ag(I) from aqueous solutions by Klebsiella sp. $3 S 1$. J. Hazard. Mater. 2017, 329, 166-177. [CrossRef]

Sample Availability: Samples of the fungal biomass are available from the authors. 